\title{
透析サテライト施設での腎移植指導の検討
}

\author{
中原宣子吉田廣子福岡由美子二宮直子 \\ 播磨政子 中谷達也* 山上征二* 岸本武利* \\ 柴田良治診療所 大阪市立大学泌尿器科*
}

key words : 維持透析患者, 腎不全治療, 移植指導

〈要旨〉

慢性腎不全患者の最終的な治療として, 腎移植は近年増加する傾向にある. 危れに伴い透析施設での対応および患 者指導は重要な意味を持ってきた.

そこで, 今回サテライト施設での腎移植の取り組みについて検討を行った. 透析患者のうち腎移植希望者を対象に, 移植知識収得期, 移植準備期, 移植待機期と 3 期に分け指導を行った。第 1 期の知識収得期では, 透析と腎移植の相 違, 移植の社会的, 医学的特徵を患者レベルに合わせて教育を実施した。第 2 期の準備期では, 生体腎移植, 死体腎 移植希望者に対し, 組織適合検査およびレシピエント登録を実施した。待機期である第 3 期では, 移植を受け入れら れる心理的側面と賓血, 二次性副甲状腺機能六進症をはじめとする移植を阻害する合併症の改善をめざし指導と治療 を行った。

以上の指導と対応を通し, 移植希望患者の認識を高めることができた. 今後も, 移植に対する教育をサテライト施 設として続けていく必要があると考える.

\section{Study on instructions for patients in dialysis facilities before kidney trans- plantation}

Noriko Nakahara, Hiroko Yoshida, Yumiko Fukuoka, Naoko Ninomiya, Masako Harima, Tatsuya Nakatani*, Seiji Yamagami*, Taketoshi Kishimoto*

Shibata Ryoji Clinic ; Department of Urology, Osaka City University*

The number of kidney transplantation cases has gradually been increasing in Japan. Along with the growth in the number of transplantation patients, the management and instruction provided for these patients by their dialysis facilities have also become increasingly important. Therefore, we studied ways for patients to cope with transplantation problems in a satellite facility. We instructed patients who were on dialysis in this hospital and who wished to undergo kidney transplantation by dividing the preparation time frame into three periods. I . Learning period : Patients were educated about the differences between dialysis and kidney transplantation and social and medical characteristics of transplantation, according to the patients' comprehension level. II. Preparation period : HLA tests and recipient registration were completed for those who desired to have living or cadaver kidney transplantation. At the same time, we conducted case studies with the assistance of those who had experienced transplantation in the past, in order to help the prospective recipients cope with the expectations and anxiety of the transplantation. III. Transplantation waiting period: We treated and instructed the patients on methods of preventing possible complications that disturb transplantation, such as anemia, and secondary hyperparathyroidism. In conclusion, by means of proper instruction and management we were able to enhance the understanding of patients who wish to have kidney transplantation. We consider it necessary to continue to provide prospective patients with adequate and effective education on transplantation.

中原 宣子 柴田良治診療所 テ 545 大阪市阿倍野区阿倍野筋 1-3-15（阿倍野共同ビル 7 F) (06-621-1301)

〔受付: 平成 4 年 6 月 24 日, 受理: 平成 4 年 9 月 18 日〕 


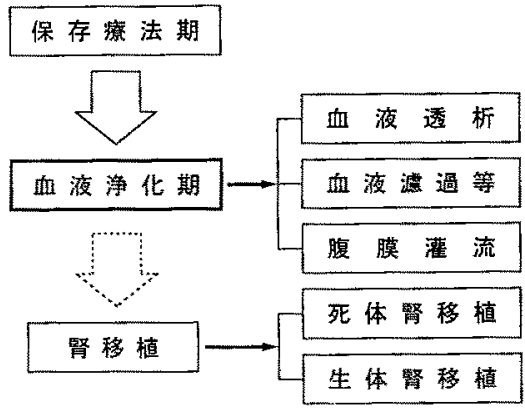

図 1 腎不全患者の治療

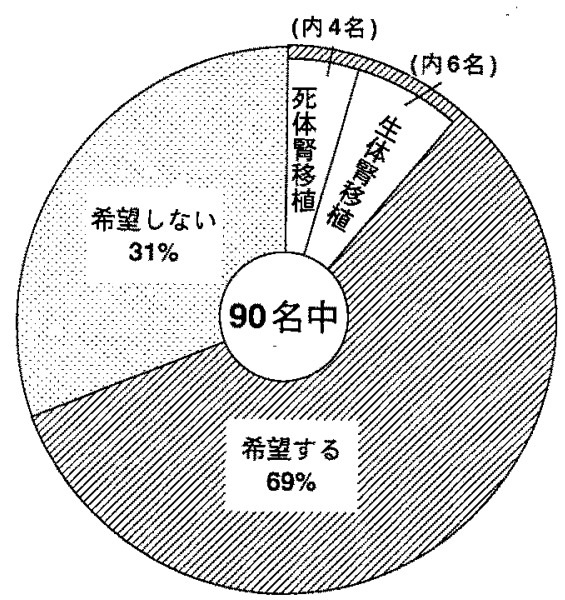

図 2 死体腎移植希望者数

\section{緒言}

1964 年より日本でも慢性腎不全の根治療法として, 警 移植が実施されるようになっだ、当院で移植を希望す る患者は，維持透析患者全体の半数以上を占めている. また，実際に移植を受けた患者は生体，死体緊移植を含 めて, 過去 3 年間において 10 名に至っている. 増加傾问 にある腎移植についてサテライト施設としての対応およ び患者指導が必要になってきた。そこで, 移植経験者敊 よび移植希望者にアンケート調査を行い, 今後の透析室 看護のあり方を検討した。

\section{透析と移植}

慢性腎不全治療の原則は, 図 1 に示すように, 保存潦 法期から血液净化期に移行する。そのうちの数パーセン トが生体腎あるいは死体腎移植の適応と実施を受けるこ とになる。

透析患者数は，毎年約 7,000 8,000名と增光続奶，日 本透析療法学会の調べにると, 1990 年で 103,296名で ある、それに対して, 㹂移植数は 800 例にも満たない2). これはドナ一不足をはじめとする移植を取りまく社会 的, 文化的等の種々の問題が考えられるがここでは触れ

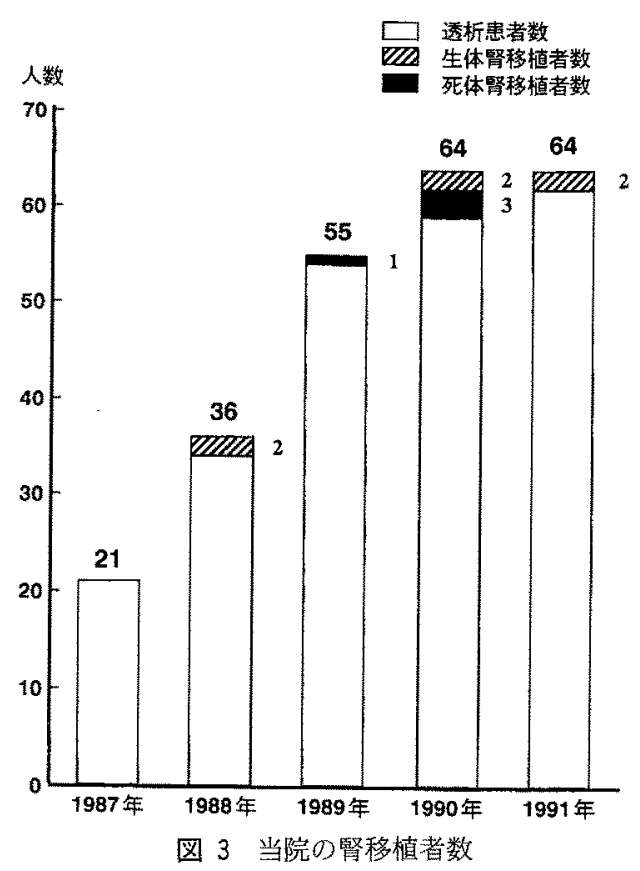

ずにおく ${ }^{3,4)}$.

図 2 \&当院の延べ患者 90 名中の移植希望患者の割合 を示している，69\%にあたる62名が移植を希望してお り，そのうち4名が死体腎移植，6名が生体腎移植を受 けている.31\%にあたる 28 名の患者は移植を希望してい なかった。その理由は 2 名が宗教的な理由をあげている 他は高囹であるためであった。

次に筒移植を受けた患者数を図3に年度别に表した。 1987 年に開設した当院は, 翣 1988 年, 1990 年, 1991 年 と2名ずつの生体腎移植を受けている.1989年からは, 死体檑移植の対象者があり，1990 年には患者数 64 名中 3 名が死体謷移植を受けている。

\section{アンケート調查結果}

婜移植を受けた患者の実態を把握するために1991年 5 月にアンゲート調查を行った，対象は，当院で生体お よび死体珡移植を受けた患者 10 名である。

図 4 に示すように，移植を受けるまでの透析期間は 8 か月から最長 5 年 9 か月である. 生体・死体腎に分けて みると，生体筒移植は 8 か月から 1 年 8 か月までで，平 均 1 年 1 加居体繁移植に比べて透析年数の浅い時期 に行すれている。

これは，生体淑移植は計画的に行うことができ，透析 導入後 1 年ぐらいまでを目処としているためと思われ る.

クレアチニンは 9 名中 7 名が $2 \mathrm{mg} / \mathrm{d} l$ 以下で他の 2 名仗 $2.1 \mathrm{mg} / \mathrm{d} l$ と $2.3 \mathrm{mg} / \mathrm{d} l$ であった。 

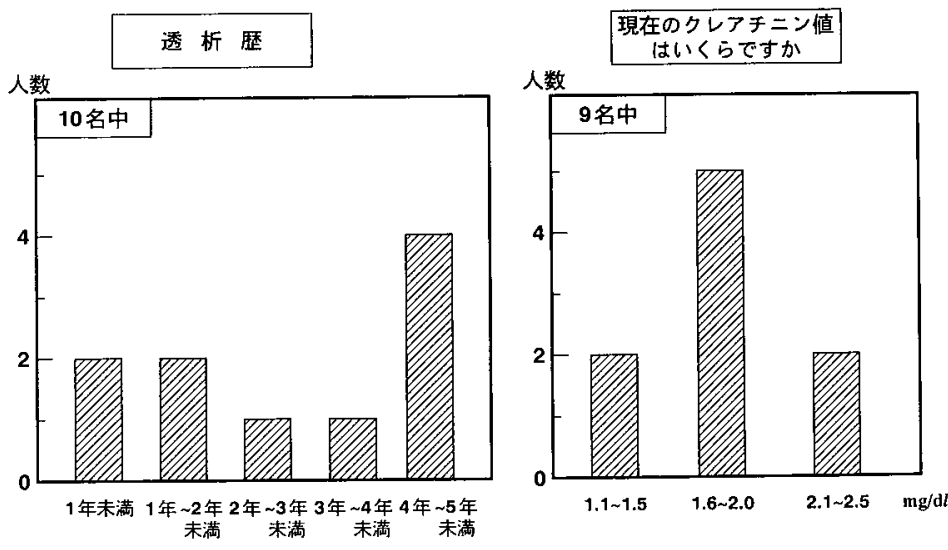

図４腎移植体験者のアンケート調査一結果 1 -
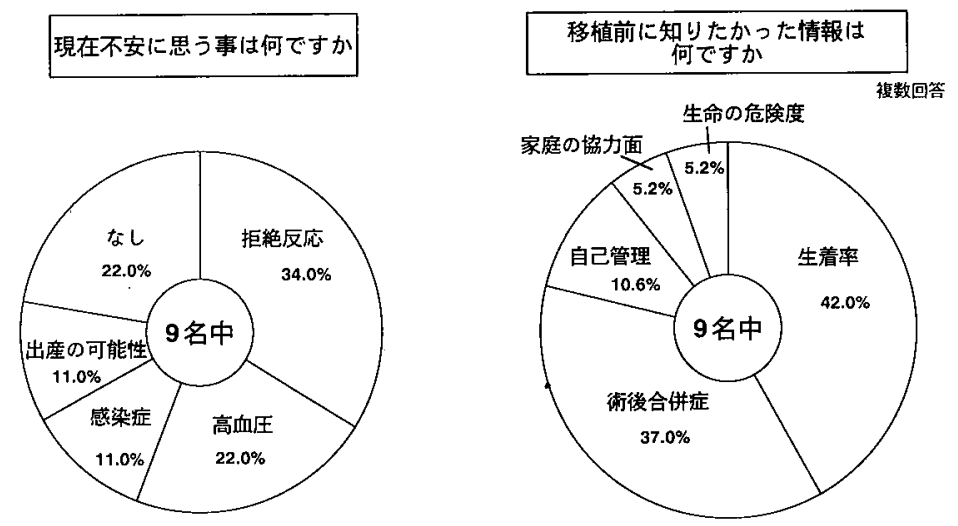

図 5 腎移植体験者のアンケート調査一結果 2 -

o 20 40 60
1) 生着率に対する不安

2) 術後合併症の不安

3) 自己管理の不安

4) 生命危険度の不安

6) 家族に関する悩み
5) 経済的な悩み

図 6

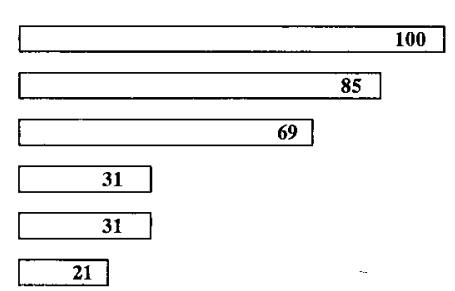

48 名中（複数回答）

体調面については，1名がステロイドによるものと思 われる白内障と大腿骨頭壊死が出現していたが, 他は良 好であった。

次に，特に不安に思うことはないかとの問いには，図 5 に示すように拒絶反応が多く, 次いで高血圧, 感染症 であった，また，出産を強く望み移植を受けた女性は， その希望と裹腹に漠然とした妊娠, 出産の可能性への不
安を表していた。

また，移植を受ける前に知っておきたかったことは何 かについて調べた。生着率，術後の合併症，自己管理の 具体的内容, 生命の危険度等，手術や移植に直接関係す る事項が多かった。その他，移植術に備えての家族等の 協力がどれぐらい必要であるか事前に知っておくと，よ りスムーズに移植を受けることができたという意見もみ られた。

図 6 は,現在当院で腎移植を希望している患者 48 名に 移植を受けるにあたり，不安に思うことをまとめている。 全員が生着率に対して不安を持っていた。これは，「移 植」と「拒絶反応」は切り離せないイメージを抱えてい るとともに，数年前のデー夕や患者から患者への口コミ の情報等によるものと思われる、続いて，術後合併症や 自己管理への不安が多く，移植後の患者の「知りたかっ た情報」と一致している。また，移植を受けるとどれく らい費用がかかるのか等といつた経済的不安もみられ 


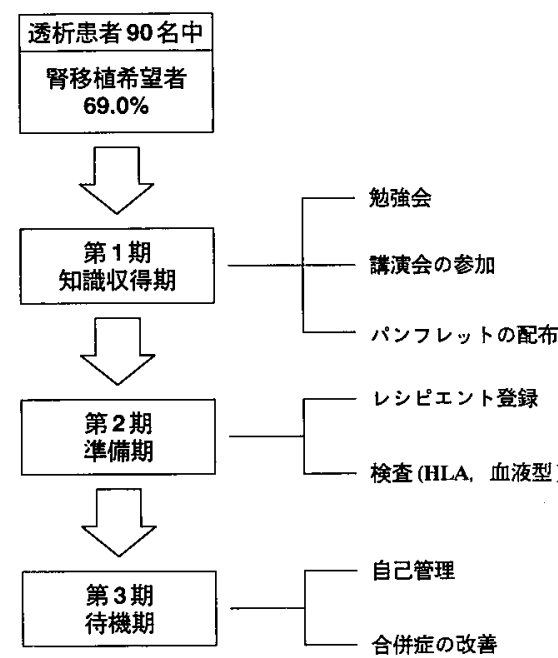

図 7 腎移植希望者の指導内容

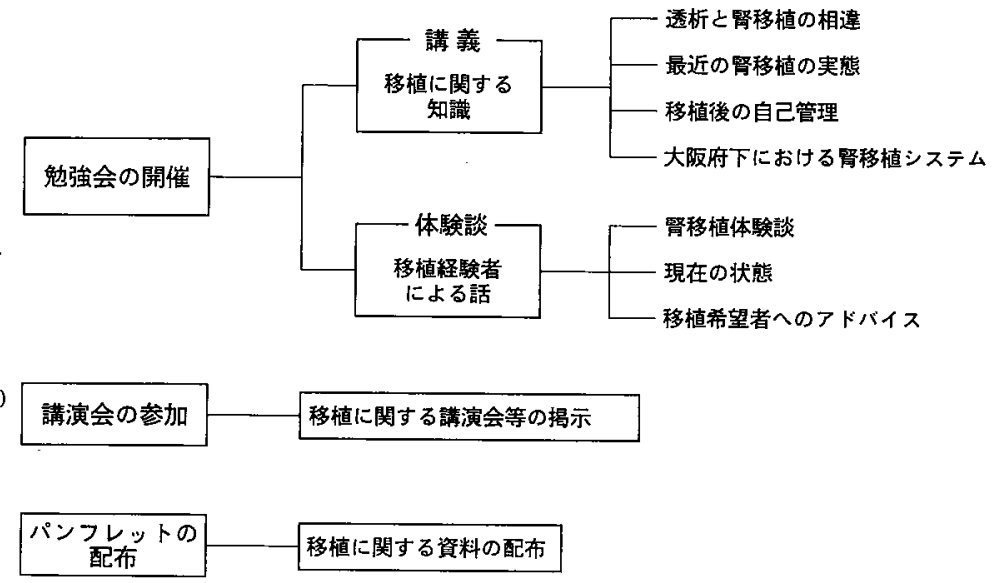

図 8 第 1 期（知識収得期）における指導内容

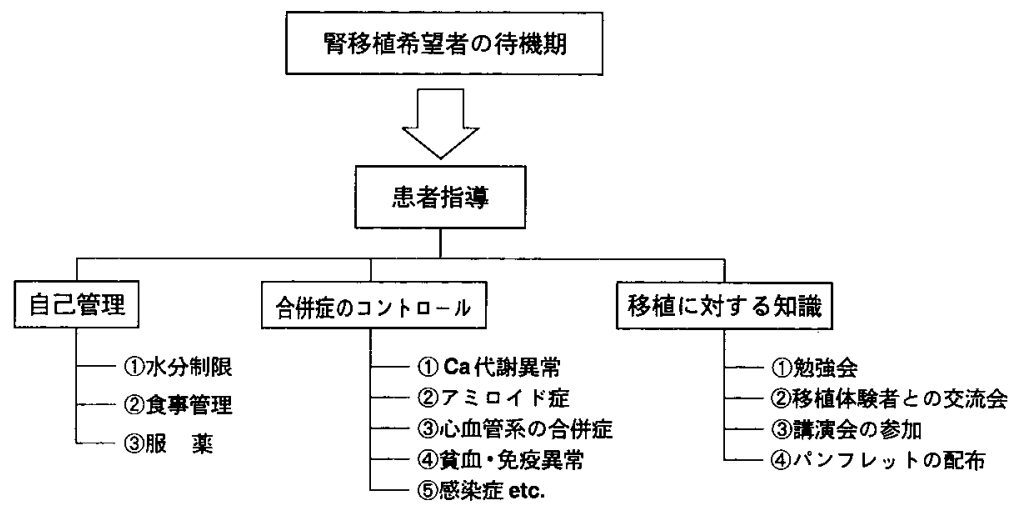

図 9 透析従事者の今後の課題

た.これらについては，移植を受けるときに初めて説明 を聞くというケースが多く，事前に情報を提供する必要 があると思われた。

\section{腎移植希望者の指導}

そこで，移植を希望する患者を対象に，段階的なケア を施行した。

図 7 に示すように患者の移植を希望した時期に応じ て, 知識収得期, 準備期, 待機期と 3 期に分けた。

第 1 期の知識収得期には (図 8), 勉強会を開催し, 移 植の基本的な知識一合併症を含めた透析と腎移植の相 違, 最近の䯚移植の生着率, 生存率一また, 移植後の自 己管理の必要性とその方法, 大阪府下における腎移植シ ステムと移植施設の紹介を行った。これらにより移植医 療の概要を理解し，認識を高めることができた。

また，当院で移植を受けた患者に同席を依頼し，個々 の移植体験を語ってもらった。これは, 生の声を目の前
で聞くことにより移植を待つ患者にとつて，細かい疑問 点や，不安感を解決する機会となった。

同時に講演会の揭示や移植に関するパンフレットの配 布を行い多方面から知識を深め理解を促した。

第 2 期の準備期では, 生体腎, 死体腎移植希望者に対 して組織適合検査执よびレシピエント登録を実施した。

第 3 期の待機期では，移植を受け入れられる心理的側 面の看護と, 移植を阻害する合併症の改善をめざし指導 と治療を行った。

\section{考察}

数年前までは，腎不全治療を患者に説明するときに， 単に紹介に終わっていた腎移植が最近では移植を待つ患 者にとって身近なものになってきている，ところが移植 を希望し登録をしているにもかかわらず，患者の意識は 漠然としたものにすぎない，そのため，特に死体腎移植 のように移植を受けるのに数時間というタイムリミット 
を要する場合に，患者は精神的にも十分な準備ができず に移植に臨んでしまうケースが少なくない。また，拒絶 反応，ステロイド剤の副作用や合併症などについて中途 半端な理解しか持っていない場合も多い.これらが原因 し, 腎移植後の患者は不安や焦燥状態などのさまざまな 精神障害が発生することがある, ${ }^{5,6)}$.

以上により，移植希望患者を持つ透析サテライト施設 としても図 9 に示すように，日常的な患者の自己管理指 導, 合併症の予防と早期発見, 治療に加えて, 移植に対 する認識を高めるための教育・指導を新たに組み入れる 必要があると考元る，それらにより，腎不全治療全体を よりスムーズに進めることができると思われる。 まとめ

1. 当院サテライトでの維持透析患者の腎移植希望者 は，69\%であった。

2 . 当院過去 3 年間における腎移植施行者は 10 名, そ のうち生体腎移植者 6 名, 死体腎移植者 4 名であった.

3. 移植希望者に対しては, 導入期からの系統的な学
習指導をされるべきである。

4. 移植希望者に対しては医療的な準備と同時に精神 面および看護面での段階的教育が必要と思われた。

5.サテライトにおける維持透析患者の腎移植に対す る施設側の対応が強く望まれる。

\section{文献}

1）太田和夫：腎移植その夢と現実. 透析会誌 24 ： $1539-1545,1991$

2）日本移植学会：腎移植臨床登録集計報告 (1990). 移 植 $26: 494-517,1991$

3) 西岡芳樹 : 脳死・臟器移植問題と人権. 脳死と臟器 移植を考える，p 103-131，メディカ出版，大阪，1989

4) 両角國男: 腎移植に伴う社会的問題. 臨床透析 6 (8 月別冊) : 17-21，1990

5）佐藤喜一郎：腎移植レシピエントの精神医学的問 題. 臨床透析 $8: 80-84,1992$

6）堀越由紀子,上村協子：QOL スケールにみる腎移植 患者の生活観. 臨床透析 6 (別冊)：356-363, 1990 